Cœnolestes. The sparassodonts (Prothylacinidæ) are also included in this radiation, although how these terrestrial types (which, as already stated, the author thinks were probably allied to the thylacine) were developed from arboreal forms is left unexplained. Finally, in the Pliocene occurred the irruption into South America of the modern opossums of that country.

It may be added that the author classifies modern marsupials by the foot-structure rather than by the dentition, thus making the two main groups Didactyla and Syndactyla, in place of Polyprotodontia and Diprotodontia.

R. L.

\section{CONTRIBUTIONS TO THE SCIENCE OF} $M E D I C I N E .^{1}$

THE handsome volume under notice contains a number of important papers of considerable interest to the physiologist, pathologist, and physician. It commences with a description, and an account of the opening, of the Johnston Laboratories for Biochemistry, Tropical, and Experimental Medicine, the munificent gift of Mr. William Johnston-hence the addition in the title of these reports. This has a melancholy interest also, since one of those who replied to the toasts on that occasion was the late Prof. Nocard.

The first paper is by Prof. Moore on the synthesis of fats accompanying intestinal absorption, in which it is shown that absorbed fat is re-synthesised to neutral fat in the intestinal mucous membrane. Neurology is represented by papers on the physiology of the cerebral cortex in anthropoid apes, by Dr. A. S. Grünbaum and Prof. Sherrington (reprinted from the Proceedings of the Royal Society, London), and on the electric conductivity of mammalian nerve, by Dr. Woodworth. Prof. Sherrington records a number of experiments carried out for the special chloroform committee of the British Medical Association on the dosage of the mammalian heart by chloroform; these have already been referred to in the columns of NATURE. Dr. Hume publishes a method for the isolation of the typhoid bacillus, based upon the greater motility of this organism compared with that of the colon bacillus, with which it is generally associated, so that the former will reach the surface of a column of viscid medium sooner than the latter when the two are introduced at the bottom. Mr. Roaf contributes a note on the influences of fiour and allied substances upon the typhoid bacillus, from which it would seem that emulsions of flour are inhibitory to the growth of this microbe. Dr. J. W. Stephens describes a modification of the Van Ermengem method for flagella staining.

The study of cancer is represented by two important papers, one by Dr. Prowse on the relation of vesicular mole to chorion carcinoma, the other by Mr. Keith Monsarrat on an organism associated with mammary carcinoma. In the last-named it is claimed that by the use of a special culture medium, round encapsuled organisms have been cultivated, the cultures in certain instances producing nodules of growth when inoculated into guinea-pigs.

The vitality of the Liverpool School of Tropical Medicine is evidenced by several contributions. Prof. Ronald Ross describes his "thick film" process for the detection of malaria and other parasites in blood. Dr. Christy and Dr. Stephens contribute papers on "tick fever" and on "blackwater fever" respectively, and Drs. Stephens and Christophers give a summary of researches on native malaria and blackwater fever, and suggestions for the prevention of these dread scourges.

Finally, the volume concludes with the report of the malaria expedition to the Gambia in 1902, by Mr. Dutton, to which an appendix is contributed by $\mathrm{Mr}$. Theobald on the mosquitoes collected in that expedition, with a description of some new species. Every paper contains the results of original work or observations of value, and the general "get up" of the volume is all that could be desired, the illustrations being numerous and excellent.

R. T. HeweETr.

1 "The Thompson-Yates and Johnst on Laboratories Reports." Vol. $v$ (New Series.) Part I. (London: Longmans, Green and Co., 1903.) NO. I 786 , vOL. 69]
UNIVERSITY AND EDUCATIONAL INTELLIGENCE.

Cambridge. - It is proposed to " affiliate" the University of King's College, Nova Scotia. Graduates in arts of that university will be admitted to the privileges of alfiliated students, namely, exemption from the previous examination and permission to proceed to the B.A. degree after six terms' residence in Cambridge.

An annual prize in civil engineering, of the value of about I $5 l$. has been founded by Mrs. Wimbolt, in memory of her late husband, Mr. J. S. Wimbolt, M.A., of Trinity College. The prize is open to Bachelors of Arts, and will be given for the best exercise or dissertation embodying the results of independent research in some subject related to the profession of a civil engineer.

THE Finance Committee of the Liverpool Corporation has decided to recommend the city council to grant to the Liverpool University 10,00ol. during the year 1904, such sum to be paid out of the city rate.

At the Northampton Institute, Clerkenwell, on Friday, February 26, Lord Kelvin will present the certificates and prizes on the occasion of the annual prize distribution and conversazione of members and students.

A CONFERENCE on nature-study, arranged by the School Nature Study Union, will be held on Saturday, January 30 , at the Passmore Edwards' Settlement, Tavistock Place, W.C. The chair will be taken by Mr. Cyril Jackson, Chief Inspector, Board of Education, and two short papers will be read by representatives of elementary and secondary schools.

\section{SOCIETIES AND ACADEMIES. LONDON.}

Royal Society, December 10, I903.- "On the Resemblances Exhibited between the Cells of Malignant Growths in Man and those of Normal Reproductive Tissues." By J. Bretland Farmer, J. E. S. Moore, and C. E. Walker.

The object of the communication is to direct attention to certain important cytological transformations exhibited during the development of malignant growths in man. The changes described appear to be diagnostic of malignant as opposed to benign growths, inasmuch as they seem to be absent from the latter class of tumours. Briefly, the authors have identified, within the proliferating edges of advancing growths, cells that exhibit a type of karyokinesis presenting an extraordinary similarity to, if not identity with, the heterotype mitosis that forms so constant a character during the production of sexual cells. This mitosis, or nuclear division, is remarkably different in character from the other divisions in the body-cells, and is recognised with ease and certainty. The nuclear chromasomes pass through a totally different series of changes as compared with those exhibited by the chromosomes of ordinary nuclei. Not only in shape is this difference manifested, but also in the reduction of their number to onehalf; and in all the subsequent cell generations that follow from a cell that has once passed through the heterotype mitosis the reduced number of chromosomes is retained in normal cases that lead to the direct formation of the sexual cells themselves. In any cells, otherwise of similar (heterotype) origin, that are not about to form actual sexual cells, variations and abnormalities may supervene.

All the principal varieties that are commonly met with during the evolution of the sexual cells have been identified in malignant growths of carcinomatous and sarcomatous types. The authors consider themselves justified in relating the malignancy of the growth with these facts, and they regard the malignant tissue in question as having originated in cells that have lost their somatic character, and have directly assumed the, nature of reproductive tissues.

They propose the term gametogenic to signify tissues that are potentially or actually about to give rise to sexual cells (gametes), whilst they call the cells that have passed through the metamorphoses indicated above, but which do not finally form functional gametes, gametoid. This expression is thus intended to embody their conclusion that the 
so called "cancer cells" are not, indeed, functional gametes, but essentially of a similar character.

They point out that the origin of gametogenic cells from somatic tissue is a common feature in plants, but its occurrence is obscured in animals because it involves a pathological condition. They further point out that parasitic habit of the neoplasm finds its analogue in the normally parasitic character of the gametogenic tissue of plants.

Linnean Society, December 17, 1903.-Prof. S. H. Vines, F.R.S., president, in the chair.-The Rev. T. R. R. stebbing, F.R.S., exhibited :--(I) A house-spider (Tegenaria sp.) with its cylindrical dwelling in the coiled feather of an Indian fan. The fan which the spider adapted to its purposes had been hanging up in a drawing-room at Jerusalem. The spider, forwarded by Miss FitzJohn to Miss Grace Stebbing, reached England alive. (2) A solid gnaur or excrescence upon the root of Cupressus macrocarpa, sent for exhibition by Mr. F. G. Smart, of Tunbridge Wells; it was eleven inches in circumference.-On the Docoglossa; an evolutionary study: H. J. Fleure. The Docoglossa are a division of gastropod molluses for which the stout teeth oin the lingual ribbon have suggested a name literally meaning "beam-tongued." The "nmmon limpet is a sufficiently familiar representative of this רוס. Mr. Fleure's essay aims at showing that the group, within the limits which he defines, is a natural one. To arrive at the structure of the common ancestor, he uses "the facts of comparative anatomy and the few known details of palæontology and embryology for the reconstruction of docoglossan history.' Admitting the preliminary character of this evolutionary study, based on the examination of comparatively few types, he appeals to zoologists for further material on which he may extend his researches.-A brief account of new researches in cancer : Prof. J. Bretland Farmer, F.R.S. The author referred to current theories of cancerous growth, and then proceeded to state his own discovery that the cytological changes in malignant growth resemble those exhibited by sporogenous or gametogenous tissues in plants and animals, in the occurrence of the form of nuclear division known as heterotype, as distinguished from the more usual homotype division.

Royal Astronomical Society, January 8.-Prof. H. H. Turner, president, in the chair.-Mr. Conrady read a paper on the chromatic correction of object glasses.-Mr. Wm. Ellis read a paper on auroras and magnetic disturbances.Mr. Maunder read a paper by Mrs. Maunder on a suggested connection between sun-spot activity and the secular change in magnetic declination.-Mr. Maunder also read a paper by himself (communicated by the Astronomer Royal) on the " great " magnetic storms from 1875 to 1903 , and their association with sun-spots, as recorded at the Royal Observatory, Greenwich. The data given in the paper showed a remarkable number of ooincidences between the appearance of large spot groups and the occurrence of the greater disturbances in terrestrial magnetism.--Prof. Turner gave an account of the observations of variable stars made under the direction of the late Sir C. Peek at Rousdon Observatory, Lyme Regis. Prof Turner had undertaken to edit and discuss the observations, which would be shortly published in the Memoirs of the Society.-Mr. Tyson Crawford showed a new finder eyepiece and a sketching board arrangement for the telescope.$\mathrm{Mr}$. Wesley read a note on Mr. Ritchey's photographs of the nebula in Andromeda. The transparency which $\mathrm{Mr}$. Ritchey had sent to the Society had been taken from negative in which the dense central portion had been reduced with a weak reducing solution, so as to show on the same photograph the details both in the dense centra and the faint outlying parts of the nebula. Mr. Wesley had carefully compared this transparency with some untouched negatives which $\mathrm{Mr}$. Ritchey had since sent, and concluded that the local reduction had produced no false detail or spurious effects.-Mr. Hinks showed photographs of the Orion nebula by Mr. W. E. Wilson, in which the detail in the central portion had been brought out by differential printing, instead of reduction of the negative.

\section{EDINBURgh.}

Royal Society, December 7, 1903.-Dr. Robert Munro, vice-president, in the chair.-The Keith prize for i899No. 1786 , VOL. 69]
Igor was presented to Dr. Hugh Marshall for his discovery of the persulphates and for his communications on the properties and reactions of these salts, published in the Proceedings of the Society. The Makdougall-Brisbane prize for $1900-1902$ was presented to Dr. Arthur T. Mastermen for his paper entitled "The Early Development of Cribella Oculata (Forbes), with Remarks on Echinoderm Development," printed in vol. xl. of the Transactions of the Society.-In a paper on the bull trout of the Tay and of the Tweed, Mr. W. L. Calderwood discussed the identification of this important migratory species, and gave reasons for the view that the "Tay bull trout was a true salmon, which has undergone modification of probably a temporary nature. while the Tweed fish was a trout regarded as the proper representative of $S$. eriox, now classed as a variety of S. trutta.-Mr. J. G. Goodchild read a paper entitled "Field Evidence Relating to the Modes of Occurrence of Intrusive Rocks," in which he gave a detailed description of a number of cases in which intrusive rocks had clearly replaced their own volume of the rocks they invade. Hughes in 1868, and Clough in 1880 , had indicated cases of this kind, and had considered that the country rock so replaced had been dissolved, and that the composition of the product had been equalised by circulation. Mr. Goodchild supported this view, and gave an outline of what appeared to be the modus operandi. The chief factors concerned were:-( $\mathrm{x})$ the heat generated by dynamic causes, connected chiefly with terrestrial disturbance; (2) the presence of saline constituents existing in solution in sea-water or in the inland lakes of arid regions, which found their way to the foci of volcanoes and there underwent concentration by prolonged boiling; and (3) the influence of pressure arising partly from the generation of steam and partly from the dynamic causes to which the volcanic heat was mainly due. He concluded with some remarks upon the differentiation of the magma originating in this way, and the possible effects which might arise from a potash magma invading an older set of rocks which had consolidated from an earlier soda magma.

December 21, 1903.-Prof. Flint, vice-president, in the chair.-Prof. Schäfer read a paper on the relative efficiency of certain methods of performing artificial respiration in man. After describing the apparatus he had devised for the accurate measurement of the air inspired and expired per minute, he proceeded to compare the various methods associated with the names of Sylvester, Howard, and Marshall Hall, and showed by actual numbers that these all fell short of the natural breathing, the least efficient being Sylvester's, in which the chest is expanded and contracted by motion of the arms. This method, which was still in common use for resuscitation from drowning, was absolutely condemned. The Howard method was moderately efficient, and was most in favour among medical men. The Marshall Hall method was somewhat less efficient than the Howard, and had the further objection of being more complicated. More efficient than any of these, and remarkably easy to perform, was the "Schäfer " method, in which the subject was placed in the prone position and an intermittent pressure applied on the lower ribs by the mere weight of the operator's body, which was swung backwards and forwards some thirteen times a minute. $\mathrm{By}$ this method 6760 cubic centimetres per minute were forced through the lungs as against 5850 cubic centimetres which passed in natural breathing.-Dr. C. E. Fawsitt gave an account of certain physicochemical investigations in the amide group. From determinations of the change of conductivity produced by the addition of an amide to acid, alkali, and neutral salts, he concluded that the amides have no acid character, but only basic properties. Accordingly, the amide group is better represented by the formula

$\mathrm{O}$
$-\mathrm{C}-\mathrm{NH}$ than by the formula $\begin{gathered}-\mathrm{C}=\mathrm{NH} \\ \mathrm{O}-\mathrm{H}\end{gathered}$ The change of conductivity produced by the addition of an amide to a neutral salt is a viscosity effect. The viscosity of solution of acetamide and carbamide follows very closely the formula $y_{a}=A^{a}$, where $y$ is the viscosity with concentration $a$, and A is a constant.-In connection with Sir John Murray's bathymetrical survey of the Scottish fresh-water lochs, Mr. James Murray gave a preliminary note on the biology of 
Loch Ness. The organisms found were grouped under the three headings, pelagic, littoral, and abyssal. All the pelagic forms and most of the abyssal forms extended into the littoral region, but the littoral forms (which were by far the most numerous) were rarely found in the open waters. A comparison of the organisms found in spring and in autumn showed that there was little seasonal variation, the chief difference being the greater number of Rotifers in autumin and the presence of certain species of Cladocera in the later season. A remarkable vertical migration of Leptodora was established, the animal coming to the surface in great numbers immediately after sunset, and retiring to a depth of roo feet or more during the day. The study of tha animals obtained from the deep muds had led to many interesting results. The Rotifers in the abyssal region differed from specimens got nearer shore, but not enough to lead to their classification as distinct species. One main difference was in the size of the eyes.

\section{Dublin.}

Royal Dublin Society, December I5, 1903. - Prof. W. F. Barrett, F.R.S., in the chair.-Prof. T. Jonnson read a paper on willow canker. The author gave an illustrated account of an osier canker due to Physalospora gregaria, Sacc., a hyalosporous sphæriaceous Pyrenomycete, which is recorded in "Sylloge Fungorum," on Prunus, Salix, Alnus, Rosa, \&c., in Italy, France, Siberia, and South America. The ascosporous stage is associated in the cankers with two others-pycnidia with triseptate conidia, and pycnidia with bisporous intercalary conidia on branching hyphæ. Economically the fungus does great harm, killing many of the osier sets outright, and in other cases spoiling the rods for basket-work. The author has traced the fungus from the sets first planted with the rods cut from year to year, and has also found the disease to be present in the osier holt in England from which the original sets were supplied. Experiments in infection and in prevention were also described.-Dr. Henry $H$. Dixon and Dr. J. T. Wigham presented a paper on the action of the radiations from radium bromide on some organisms.

\section{PARIS.}

Academy of Sciences, January 11.-M. Mascart in the chair.-The action of the X-rays upon animal tissues: $\mathrm{R}$ Lépine and $\mathrm{M}$. Eoulud. The $\mathrm{X}$-rays favour the formation of amylase in the pancreas. In the liver and in the blood, their first action is to increase glycolysis, but this effect is diminished, or even arrested, by their prolonged action.-M. Lacroix was elected a member in the section of mineralogy in the place of the late M. Munier-Chalmas. - On the asymptotic study of meromorphic functions: M. Émile Eorel.-On the homographic resolution of spherical triangles: M. d'Ocagne.-On the properties of notched test-pieces : Aug. Pourcel.-On a self-recording apparatus allowing of the measurement through a solid wall, carrying pressures relatively high, of small differences of pressure: M. A. Mesnager.-On a method for the comparison of thicknesses: M. Mesnager. In the method of MM. Pérot and Fabry a thin layer of air between two halfsilvered glass plates making a small angle with each other is utilised. The delicacy of the measurements is increased two hundred times by replacing the air film by a thin plate of quartz. The quartz plate, placed between two parallel Nicols, gives the same fringes as the half-silvered plates, but 218 times larger. This arrangement also possesses the advantage of absorbing much less light than the compensator with half-silvered plates, and also avoids the confusion resulting from multiple reflections.--On the production of the $n$-rays by sound vibrations: J. Macé de Lépinay. The fact that the compression or extension of a body gives rise to the n-rays led to the conclusion that sound vibrations would produce the same effects, and this conclusion has been experimentally confirmed.-On the applications of the chronostiliscope: E. Varenne and L. Godefroy.Colour reactions of vanadic acid and ethenol: Camille Matignon. The colour reaction obtained with vanadic acid and some specimens of ordinary ether has been traced to the presence of ethenol, vinyl alcohol.-The use of bismuth as a separating agent for the rare earths: G. Urbain and H. Lacombe. On adding to uncrystallisable mother liquors of the rare earths their own weight of the double nitrate of magnesium and bismuth, the latter carries down the gadolinium in crystallising, the operation being repeated until the soluble earths no longer give the spectrum of gadolinium. This method of extraction works equally well in the elimination of gadolinium from crude yttrium earths.-A new method of estimating the halogens in organic compounds. The case of chlorine and bromine : A. Eaubigny and G. Chavanne. The compound is oxidised by heating with a mixture of sulphuric and chromic acids, the halogen being caught in an alkaline sulphite solution. Analytical results are given showing the accuracy of the method.--The titration of manganese "Léon Déhourdeaux. The oxide is dissolved in a solution of sulphuric and oxalic acids, the active oxygen being measured by the amount of oxalic acid destroyed, and from the amount of sulphuric acid used up the quantity of hydrochloric acid required by the oxide in the commercial preparation of chlorine can be calculated.-On a new general method for the synthesis of aldehydes: MM. Béhal and sommelet. Aldehydes of the types $R_{2} \cdot C H . C H=O$ and $\mathrm{RR}^{\prime} . \mathrm{CHCH}$ : $\mathrm{O}$ are obtained by heating $\alpha$-glycols of the type $\mathrm{RR}^{\prime} \cdot \mathrm{C}(\mathrm{OH}) \cdot \mathrm{CH}_{2} \cdot \mathrm{OX}$ with oxalic acid. The glycols are readily obtained by Grignard's reaction from the ketones R.CO. $\mathrm{CH}_{2} \cdot \mathrm{OC}_{2} \mathrm{H}_{5}$. The properties of a series of aldehydes prepared by this method are given, in which $\mathrm{R}$ includes alkyls from methyl to isoamyl, and also allyl and phenyl. The method appears to be quite general.-The synthesis of aromatic aldehydes: F. Bodroux. Phenylmagnesium-bromide reacts with ethyl orthoformate and gives benzaldehyde, with a yield of 90 per cent. The para-tolyl magnesium bromide reacts in a. similar manner.-The stimulating influence of an albumenoid material on the oxidation caused by manganese salts: A. Trillat. The oxidising effect is increased by the addition of an albumenoid, but the effect produced is not proportional to the amount of the latter, there being a proportion producing a maximum result.-On the formation of tetrads and maturative divisions in the testicle of the lobster: Alphonse Labbe.-On the nidamental gland of the oviduct in elasmobranchs: I. Borcea.-The emission of $n$-rays by plants : Édouard Meyer. $N$-rays are emitted by plants, this emission being a function of the nutritive activity or evolution of the plant.-The morphological characters of the Acrocecidia: C. Houard.-Chronology of the cave near Mentone: Marcellin Boule. A further examination. of these well-known caves has been undertaken at the instigation of the. Prince of Monaco, and has resulted in the discovery of four human skeletons, many fossil remains of animals, and a large number of worked objects in stone and bone. The present paper contains the results of the stratigraphical study of these caves. Layers have been found corresponding to the Upper and Lower Quaternary, and a layer beneath these which appears to be pre-Quaternary.-On the earthquakes in the Andes: de Montessus de Ballore.-On the general bathymetric chart of the ocean : J. Thoulet and Ch. Sauerwein.-An experimental demonstration of the general action of the interstitial gland of the testicle on the economy: P. Bouin and P. Ancel. Contrary to the opinion of Brown-Sequard, the seminal fluid is without action on the organism, the interstitial gland alone possessing the functions generally recognised as belonging to the whole testicle.-Cooperation, hierarchisation, and integration of the sensations in the Artizoa: Georges Bohn. -Radiotherapy as a means of diagnosis and therapeutics in certain fibromas: Foveau de courmelle.

\section{New South Wales.}

Royal Society, October 7, 1903.-Mr. F. B. Guthrie, president, in the chair.-The geology of the Mittagong district: T. Griffith Taylor and D. Mawson. The authors show in this paper that the eruptive rocks of the Mittagong district are all of post-Triassic age.-Notes on some native dialects of Victoria: R. H. Mathews.

November 4, 1903.-Mr. F. B. Guthrie, president, in the chair.-On some further observations on the life-history of Filaria immitis, Leidy: T. L. Bancroft. In this paper Dr. Bancroft (who has at various times during the past fifteen years worked at filarial diseases of the human subject, the dog, and birds) has detailed the results of final work on this subject. He has suçceeded, through the agency of mosquitoes, in transmitting Filaria immitis from

NO. I 786 , VOL. 69] 
an infected to several healthy dogs, and has also observed the manner in which the young Filaria leaves the mosquito's proboscis.

Linnean Society, November 25, 1903.-Mr. Henry Deane, vice-president, in the chair.-Sur quelques Similitudes des Langues et des Coutumes des Indigènes de Funafuti (Ellice Group) et des Indigènes des Iles de la Société, de 1'Archipel des Tuamotu, \&c., by MM. Donat and seurat. The resemblances specially considered have reference to the names of divinities, temples, the cocoanut, Morinda citrifolia and the root of Cordyline; the bark girdle ornamented with feathers, and the eye-shade; the hooks and baits used in fishing, and the capture of turtles; edible Mollusca; and juvenile games. The variability of Eucalyptus under cultivation, by $\mathrm{Mr}$. J. H. Maiden. The author has been at considerable pains to obtain specimens of the Eucalypts described as new species from cultivated forms. Through the kindness of the professors of the Museum d'Histoire Naturelle at Paris, he has obtained a large number of Naudin's types, and has expressed his views as to the identity of these with spontaneous Australian forms.-Notes from the Botanic Gardens, Sydney, No. 9, by Messrs. J. H. Maiden and E. Betche. This paper continues the series of descriptions of new Australian plants, new records for New South Wales, and critical notes of special interest to Australian botanists.-On the botany of the "clears" and "basalt masses," County of Hunter, N.S.W., by Mr. A. C. Barwick.-Description of a new genus and species of Coleoptera (Fam. Hispidæ) from New Britain, by Mr. David sharp, F.R.S. The generic name Brontispa, n.gen. Chrysomelidarum (Hispides, group Cryptonychides), is proposed for this insect, which has of late done much damage in cocoanut plantations.

\section{DIARY OF SOCIETIES.}

THURSDAY, JANUARY $2 \mathrm{~T}$.

Royal Society, at 4. 30.-On the Acoustic Shadow of a Sphere, with an Appendix by Prof. A. Lodge giving the Values of Legendre's Functions from $P_{0}$ to $P_{20}$ at Intervals of 5 Degrees : Lord Rayleigh, O.M., F.R.S.The Third Elliptic Integral : Prof. A. G. Greenhill, F. R.S - On the Structure of the Palzozoic Seed Lagenostoma Lomaxi, with a Statement of the Evidence upon which it is referred to Lyginodendron: Prof. F. W. Oliver and Dr. D. H. Scott, F.R.S. - The Significance of the Zoological Distribution, the Nature of the Mitoses, and the Trans. missibility of Cancer: Dr. E. F. Bashford and J. A. Murray.-In view of the special meeting immediately following, these papers will be taken as read by printed abstract.

Roval Institution, at 5.-The Flora of the Ocean: G. R. M. Murray, F.R.S.

LinNEAN Society, at 8.-An Account of a Plankton Expedition to the Bay of Biscay in H.M.S. Research in rgoo: Dr. H. G. Fowler.-The Bay of Biscay in H.M.S. Research in igoo: Dr. H. G. Fowler.-The T. R. R. Stebbing, F.R.S.

$$
\text { FRIDAY, JANUARY } 22 .
$$

Rovai, Inititution, at 9.-Spectroscopic Studies of Astrophysical Problems at Stonyhurst College Observatory : Rev. Walter Sidgreaves, S.J.

Paysical Society, at 5.- The Photographic Action of Radium Rays: S. Skinner.-Astigmatic Aberration: W. Bennett.-Some New Cases of Interference and Diffraction: Prof. R. W. Wood.-Exhibition of Instruments by Messrs. Crompton and Co.

SATURDAY, JANUARY 23.

Royal Institution, at 3.-British Folk Song: J. A. Fuller-Maitland.

Mathematical Association, at 2.-Annual Meeting.-Models of Regular and Semi-regular Solids, including the four "polyèdres étoilés" of Poinsot, exhibited by Mr. E. M. Langley.-An Account of a Recent Discussion on the Possibility of Fusion of the Teaching of Mathematics and Science: C. S. Jackson.-A Geometrical Note: J. C. PalmerAdvanced Schuol Courses of Mathematics: C. A. Rumsey.

MONDAY, JANUARY 25 .

Socigtry or ArTs, at 8. - Oils and Fats-their Uses and Applications : Dr. J. Lewkowitsch (Cantor Lectures I.).

Roval GEOGRAPHICAL SocieTY, at 8.30.-The Geographical Pivot of History: H. J. Mackinder.

NSTITUTE OF ACTUARIES, at 5.-A Comparison of the Various Methods of Grouping Whole-Life Assurances for Valuation: D. C. Fraser.

\section{TUESDAY, JANUARY 26.}

Rnyal Instirution, at 5.-The Development of Animals: Prof. L. C. Miall, F.R.S.

Institution of Civil Engineers, at 8.-The Sanding-up of Tidal Harbours: A. E. Carey.

\section{WEDNESDAY, JANUARY 27 .}

Sociery of ARts, at 8.-Ice-Breakers and their Services: Arthur Gulston.

NO. 1786 , voL. 69]
THURSDAY, JANUARY 28.

Roval Societr, at 4.3\%.-Probable Papers: Observations on the Sex of Mice-Preliminary Paper: Dr. S. Monckton Copeman, F.K.S., and F. G. Parsons.- Observations upon the A quirement of Secondary Sexual Testicle: S. G. Shattock and C. G. Seligmann. On the Part played by Benz: ne in Poisoning by Coal Gas: Dr. R. Staehelin.- The Morphology of the Retrocalcarine Region of the Cortex Cerebri: Prof. G. Elliot Smith.

Royal Institution, at 5.-The Flora of the Ocean: G. R. M. Murray,

INSTITUTION OF ELECTRICAL ENGINEERS, at 8.-The Edison Accumulator for Automobiles: W. Hiblert. (Adjourned discussion.) To be opened by Dr. J. A. Fleming, F.R.S.- On the Magnetic Dispersion in Induction Motors, and its Influence on the Design of these Machines: Dr. H. Behn-Eschenburg. (Adjourned discussion.)

\section{FRIDAY, JANUARY 29 .}

Royal Institution, at 9.-The Marshes of the Nile Delta: D. G. Hogarth.

INSTIUUTION OF CiviL ENGINEERs, at 8.-Metallurgy as Applied in Engineering: Archibald B. Head.

SATURDAY, JANUARY 3 O.

Royal InStitution, at 3.-British Folk Song: J. A. Fuller-Maitland.

\section{CONTENTS.}

PAGE

An Evolutionary Study of European Polity. By

Sir Frederick Pollock, Bart.

A Contribution to Californian Geology. By B. B. W. 266 Physiology and Alcohol. By Prof. Benjamin Moore 267 A Book of English Sports. By R. L. . . . . . . . 267 Our Book Shelf :-

Hoskins: "Theoretical Mechanics. An Elementary Text-book"

Fritsche: "Atlas des Erdmagnetismus für die Epochen 1600, I700, r780, 1842 and 1915" .; . 268

Polkinghorn: "The Wonderful Works of God" ". 269

"Riviera Nature Notes" . . . . . . . . . . . 269

P. O. P. :"The Square Circled" ". . . 269

Kingsley:" "The Garden Diary and Calendar of Nature". . . . . . . 269

Letters to the Editor:-
Oxford Science-Dr. H. M. Vernon; Prof. John Perry, F.R.S.

An Undescribed Rudimentary Gill-plume in the Crayfish. - Prof. E. Ray Lankester, F.R.S. . . .

A Theory of the Cause of Atmospheric Electricity.-

George Simpson
Projection of Imitation Spinthariscope Appearance.The Diminishing Size of the New Bishop's Ring around the Sun.-Henry Helm Clayton

Subjective Images. -Dr. Gerald Molloy . . . . . 27I

National Science Scholarships.-W. H. Pretty : . 271

The Transvaal Technical Institute.-John Robinson 271

The Quadrantid Meteor Shower of r904.-John R. M. Blondlot's ' $u$-Ray Experiments. $\dot{A}$. A. Campbell Swinton ................

Phosphorescence of Photographic Plates.-i. 'j. Edwards

Bird-Life in Wales. (Illustrated.) By O. V. Aplin 272 Earth-Movements in the Bay of Naples. (Illustrated.) By R. T. Günther . . . . .

The Elastic Limit of Metals. (Illustrated.) By

T. K. R. . . . . 276 Prehistoric Studies in Austria. By J. E. . . . . 277

Notes . . . . . . . . . 278

Our Astronomical Column :-

Intensity of Atmospheric Lines in the Solar Spectrum 28I

Observations of Jupiter . . . . . . . . . . . 281

Meridian Circle Observations of Eros and Nova Persei 282

Periodical Comets due this Year . . . . . . . 282

Recent Conferences of Science Teachers. By

Wilfred Mark Webb .. . . . . . . . 282 The Origin of the Australian Marsupials. By R. L. 284 Contributions to the Science of Medicine. By

Prof. R. T. Hewlett . . . . . . . . 285 University and Educational Intelligence . . . . . 285 Societies and Academies . . . . . . . . . 285 Diary of Societies . . . . . . . . . . . . . 288 